\title{
Academic Library Committees: Their Role in Participative Management
}

\author{
Mary Ann Sheblé and Debra W. Hill
}

The growing number of committees in academic libraries has been equated with the rise of participative management as a way of organizing library operations. But there is little empirical evidence to support this assumption. This study examines this issue through survey data from a random sample of librarians in U.S. academic libraries. The study shows that not all libraries use committees in significant roles, and that the presence of committees does not guarantee that librarians will have a significant voice in their organization. Librarians who serve on committees with policy-related functions were positive about their committee service and about the ability of committees to benefit the organization. Librarians serving on fact-finding and information-gathering committees tended to be negative about their committee service and conservative in their belief about the ability of committees to influence the management of their organization. Smaller libraries were much more likely than larger libraries to involve committees in significant decision-making roles.

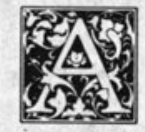

ccording to Louis Kaplan, while participative management "made its debut in the third decade of the 20th century .... in an industrial plant in ... Illinois," it was not until the seventies that the management style became acceptable in academic libraries. ${ }^{1}$ Referring to the student revolts of that decade as well as to management theories espoused by Rensis Likert, Maurice Marchant, and David Kaser, he stated that "it was the combination of violence and managerial theory that provided the combustive material" that precipitated the acceptance of the new management theory in American academic libraries. ${ }^{2}$ Participative management is an approach that stresses worker involve- ment in management decision making. ${ }^{3}$ Many have embraced this theory of management because it offers a multitude of benefits to individuals involved as well as to their institutions.

According to Maurice Marchant, "Group decision-making has two major advantages over decision-making imposed unilaterally by management; these are that group decisions tend to be of superior quality and they tend to be more readily accepted by the group." The literature supports the theory that those who participate in the decisions involving their work are much more satisfied than those who have little input. This theory certainly applies to academic librarians who thrive on their capacity to work out problems that are

Mary Ann Sheble is Associate Director for Technical Services and Systems at the University of Detroit Mercy, Detroit, Michigan 48219-0900. Debra W. Hill is Head, Monographs Unit, and Assistant Professor at the University of Alabama Libraries, Tuscaloosa, Alabama 35487-0266. 
"not neat, not well formed" but are exactly the type of problems faced by administrators. ${ }^{5}$ As professionals, often with faculty status, academic librarians expect to be involved in decision making at the goal- and policy-formation levels.

What evidence do we have of decision making by nonmanagerial professionals in American academic libraries? Maurice Marchant noted in 1971 that no study of library staff participation in decision making had been reported prior to that time. ${ }^{6}$ In 1988 Louis Kaplan reported that the number of libraries in which participative management was being practiced was still unknown.?

While the use of committees in academic libraries has become common, there is limited evidence that they are functioning as a mechanism for rank-and-file librarians to significantly influence the goals and structure of their libraries.

Perhaps one significant piece of evidence is the widespread use of committees. Richard Eggleton noted in 1979 that "academic libraries ... have found the committee process an attractive means of implementing a form of participative management." ${ }^{8} \mathrm{He}$ said that "academic libraries have found the committee structure extremely useful in studying and recommending action on a variety of technological, social, and policy issues facing libraries." Stanley Seashore is another advocate of committee use in libraries and views the committee as an important component of participative practices. At the seventy-fifth meeting of the Association of Research Libraries, Seashore suggested steps for implementing participative management in academic libraries. His suggestions include "increasing the frequency of use of committees... with membership including lower-rank people, for the preparation of proposals for technological, policy and program changes. ${ }^{10}$

Although the committee is often cited as a mechanism through which partici- pative management is implemented, there is little systematic research to support this application in libraries. Casual observation leads us to conclude that committees have become an integral part of most American academic libraries, but the role that they play in the management of these libraries is not clear. More specifically, while the use of committees in academic libraries has become common, there is limited evidence that they are functioning as a mechanism for rank-and-file librarians to significantly influence the goals and structure of their libraries. The purpose of this study is to investigate this issue through examining the following questions:

1. Who is serving on committees? Are committees in academic libraries involving professionals of all ranks, including line-level employees?

2. Are committees being used in significant ways in academic libraries? Are participants satisfied with the role that committees play in their libraries?

3. How do committees benefit their host organizations? Do participants derive any personal benefits from committee service?

4. Does committee use and effectiveness vary systematically across different types of libraries? For example, are there differences between small and large libraries, and libraries with different degrees of physical centralization?

In addition to exploring these questions, the study attempts to document the extent of committee use in academic libraries. Through this, we hope to provide a base on which other research can build to assess future directions in committee use.

\section{STUDY DESIGN}

In January 1993 surveys were mailed to a random sample of potential respondents in U.S academic libraries. The return rate was 57 percent. ${ }^{11}$ Since respondents were assured of anonymity, there were a limited number of variables 
on which we could compare respondents and nonrespondents to look for possible sources of systematic bias. An analysis of library size and position did not show any systematic differences between those responding to the survey and those who did not return their surveys.

Items for the survey were selected from the literature on committees and participative management, and from the experience we have gained by serving on committees in academic libraries. The survey instrument was pretested with a group of thirty-two academic librarians at the University of Alabama Libraries.

\section{WHAT TYPES OF LIBRARIES/ SITUATIONS EMPLOY COMMITTEES?}

The initial phase of our analysis explored the extent that committees are used in academic libraries, and identified variations in this use. ${ }^{12}$ As expected, all respondents reported that their libraries use committees and all but three respondents ( 4 percent) reported that they had served on one or more committees within the past year. All but ten respondents (14 percent) were serving on at least one committee at the time they completed the survey. On the average, the librarians in our sample reported serving on between four and five committees during the past year ( $X=4.52$ percent).

One of the most frequently cited disadvantages of committees is their significant cost to organizations, primarily in terms of staff time. Salaries paid to individual participants for time spent in meetings and preparing for meetings are one of the direct costs. Indirect costs include time away from regular duties and responsibilities, as well as personal costs to individuals for time spent on committee activities outside of regular work hours.

Despite the prevalent use of committees in academic libraries, librarians do not appear to spend as much time in committee meetings as their corporate counterparts. A survey of 1,200 corporate employees conducted by the Harvard Business Review found that their respondents spent an average of 14.6 hours per month in committee meetings. ${ }^{13}$ This compares to 6.7 hours per month reported by the librarians in our sample. In fact, over half ( 55 percent) of the librarians who responded to our survey reported spending less than 5 hours per month in meetings. But for librarians, the time spent in meetings is only the beginning of the commitment required for committee work. Respondents estimate that they spend a similar amount of time each month on committee-related work, with 61 percent of the respondents reporting that part of this work is completed outside of regular work hours.

In addition to an overview of committee participation, we looked at variations by several organizational and personal variables. The two main organizational variables tapped by our survey are the size of the library and the degree of physical centralization. Libraries were classified as having a central library only or a decentralized arrangement. Library size was determined on the basis of ARL collection categories. ${ }^{14}$ For our analysis, we collapsed the initial categories into "small" (under 300,000 volumes), "medium" (300,000, but less than one million volumes), and "large" (one million and over).

\section{Our results show that faculty status does not influence the level of committee activity in libraries.}

The degree of physical centralization does not appear to influence the extent of committee use in libraries. Librarians report a similar number of committee assignments per person and time spent in committee meetings and on committee-related work regardless of the organization of their libraries. Our analysis of the relationship between library size and committee participation shows some interesting variations (table 1). The highest level of committee participation was reported in mediumsized libraries with collections between 300,000 and one million volumes. Approximately 75 percent of all respondents working in libraries of this size reported that they had served on four or 
TABLE 1

COMMITTEE PARTICIPATION BY LIBRARY SIZE

\begin{tabular}{lcccc}
\hline & \multicolumn{3}{c}{ Library Size } \\
\cline { 2 - 5 } $\begin{array}{l}\text { Committee } \\
\text { Participation }\end{array}$ & $N$ & $\begin{array}{c}\text { Small } \\
\%\end{array}$ & $\begin{array}{c}\text { Medium } \\
\%\end{array}$ & $\begin{array}{c}\text { Large } \\
\%\end{array}$ \\
\hline $\begin{array}{l}4 \text { or more } \\
\text { committees in } \\
\text { past year }\end{array}$ & 38 & 22.2 & 75.0 & 58.3 \\
$\begin{array}{l}3 \text { or more } \\
\text { committees } \\
\text { currently }\end{array}$ & 25 & 11.1 & 55.0 & 36.1 \\
\hline
\end{tabular}

For committees in past year: $x^{2}=9.7987 ; d f=4 ; p=.0439$.

For current committee: $x^{2}=8.1147 ; d f=4 ; p=.0875$.

more committees within the past year. Respondents working in libraries with collections exceeding one million volumes reported a slightly lower level of committee participation. Respondents who work in smaller libraries reported serving on fewer committees.

We also looked at the relationship between faculty status and committee participation. Our results show that faculty status does not influence the level of committee activity in libraries. Those without faculty status reported serving on almost as many committees as did their colleagues with faculty status, and reported spending slightly more time in committee meetings and on committeerelated work.

This finding did not support our expectations. Committee service is frequently required as part of the criteria for tenure in academic libraries. In fact, 84 percent of our respondents in libraries with faculty status indicated that committee activities are considered in tenure decisions. We also expected that those with faculty status might demand a greater degree of self-governance, and that this would be reflected in a high level of committee participation in libraries with faculty status. Neither of these expectations was supported by our analysis.

\section{WHO IS SERVING ON COMMITTEES?}

One of the major tenets of participative management is the structured opportunity for employees to participate in significant organizational decision making outside of their own subordinate pyramid. If committees in academic libraries are serving in this capacity, they will show evidence of involving personnel from a variety of service areas and position levels. The level of our respondents' committee participation was measured through the following survey items:

- Number of committees served on during the past year

- Number of committees respondents were serving on at the time they completed the survey

- Number of hours per month spent in committee meetings

- Number of hours per month spent on committee-related work (excluding time in committee meetings).

Who is serving on committees and to what extent? The answer is just about everyone to some degree. Respondents in technical services reported serving on fewer committees than those in public services, special division departments, and administration (table 2). However, the relationships between service area, and time spent in committee meetings and time spent on committee-related work are highly nonsignificant. While technical services personnel may not be involved in as many committees as others, our analysis suggests that their time-commitment for committee-related work is just as intensive as their colleagues in other service areas. An analysis of committee participation variables by position level does not show any significant differences. Managers, 
TABLE 2

COMMITTEE PARTICIPATION BY LIBRARY SERVICE AREA

\begin{tabular}{|c|c|c|c|c|c|}
\hline \multirow[b]{2}{*}{$\begin{array}{l}\text { Committee } \\
\text { Participation }\end{array}$} & \multicolumn{5}{|c|}{ Library Service Area } \\
\hline & $N$ & $\begin{array}{c}\text { Tech Services } \\
\%\end{array}$ & $\begin{array}{c}\text { Public } \\
\text { Services \% }\end{array}$ & $\begin{array}{c}\text { Special } \\
\text { Departments \% }\end{array}$ & $\begin{array}{c}\text { Administration } \\
\%\end{array}$ \\
\hline $\begin{array}{l}4 \text { or more } \\
\text { committees } \\
\text { in past year }\end{array}$ & 39 & 50.0 & 63.0 & 56.3 & 100.0 \\
\hline $\begin{array}{l}3 \text { or more } \\
\text { committees } \\
\text { currently }\end{array}$ & 26 & 20.0 & 40.7 & 56.3 & 66.7 \\
\hline $\begin{array}{l}5 \text { or more } \\
\text { hours } / \text { month } \\
\text { in committee } \\
\text { meetings }\end{array}$ & 35 & 50.0 & 55.5 & 56.3 & 66.7 \\
\hline $\begin{array}{l}6 \text { or more } \\
\text { hours } / \text { month } \\
\text { on committee- } \\
\text { related work }\end{array}$ & 25 & 33.4 & 46.9 & 37.5 & 66.3 \\
\hline
\end{tabular}

For committees in past year: $x^{2}=10.2030 ; d f=6 ; p=.0332$.

For current committees: $x^{2}=10.2996 ; d f=6 ; p=.0049$.

For hours in committee meetings: $x^{2}=7.216 ; d f=6 ; p=.1719$.

For hours on committee-related work: $x^{2}=2.6912 ; d f=6 ; p=.3250$.

supervisors, and line-level employees reported serving on a similar number of committees and spending a similar amount of time on committee-related work.

\section{HOW ARE COMMITTEES BEING USED?}

An additional tenet of participative management is the involvement of rankand-file employees in significant decision making that impacts the goals and standards of their organization. To assess the extent that committees provide this opportunity for academic librarians, we asked respondents to list up to six functions that committees perform in their libraries. Responses were grouped into five categories: (1) exchanging information and ideas, (2) problem solving, (3) advising and recommending, (4) establishing policy, and (5) implementing policy (table 3 ).

The most frequently cited function of committees is "advising and recommending." In fact, over 98 percent of the respondents reported that committees are used in their libraries for this pur- pose. "Problem solving" is second in frequency and was cited by 86 percent of the respondents. This is followed by "exchanging ideas and information" (nearly 70 percent), "establishing policy" (almost 67 percent), and "implementing policy" (52 percent).

This overview shows that a number of libraries are using committees for significant activities and suggests a shift in library management policy over the past twenty years. Maurice Marchant began his 1976 publication of Participative Management in Academic Libraries with the following statement: "The normal management style in today's American university libraries is authoritarian, characterized by a director who makes decisions regulating the library but usually allows staff reaction before formalizing them."15 That approximately two-thirds of the respondents indicate that committees are used for establishing policy and over a half cite "implementing policy" as a committee function indicates that, at least in some libraries, committees are performing roles that were typically reserved for administrators in previous years. 
TABLE 3

FUNCTIONS OF COMMITTEES IN ACADEMIC LIBRARIES

\begin{tabular}{lccc}
\hline Committee Functions & $N$ of Responses & \% of Responses & \% of Cases \\
\hline $\begin{array}{l}\text { Exchanging ideas and } \\
\text { information }\end{array}$ & 48 & 18.7 & 69.6 \\
Problem solving & 59 & 23.0 & 85.5 \\
$\begin{array}{l}\text { Advising and } \\
\text { recommending }\end{array}$ & 68 & 26.5 & 98.6 \\
Establishing policy & 46 & 17.9 & 66.7 \\
Implementing policy & 36 & 14.0 & 52.2 \\
\hline
\end{tabular}

Percentages for cases add up to more than $100 \%$ because most respondents listed multiple functions.

TABLE 4

COMMITTEE FUNCTIONS BY SIZE OF LIBRARY

\begin{tabular}{lcccc}
\hline & \multicolumn{4}{c}{ Library Size } \\
\cline { 2 - 5 } Committee Functions & $N$ & Small \% & Medium \% & Large \% \\
\hline Exchange ideas and information & 47 & 50.0 & 71.4 & 73.0 \\
Problem solving & 58 & 80.0 & 85.7 & 86.5 \\
Advising and recommending & 67 & 90.0 & 95.2 & 100.0 \\
Establishing policy & 45 & 90.0 & 61.9 & 62.2 \\
Implementing policy & 35 & 70.0 & 38.1 & 54.1 \\
\hline
\end{tabular}

Respondents could reply to multiple categories of the dependent variable. Percentages are based on the number of respondents replying to each category.

Our interest centered on libraries where committees are being used for policy-related functions because this indicates a strong role for committees within the library, and suggests that committees are promoting employee involvement in the management of library operations. To better understand this relationship, we analyzed the five committee functions across organizational variables.

\section{It appears that committees in small academic libraries actually are being used more often in significant roles than in medium-sized and larger libraries.}

Library size was the only variable on which significant differences were found (table 4). The smaller the library, the more likely the respondents were to mention stronger roles for committees. Approximately 90 percent of all respondents from smaller libraries mentioned "establishing policy" as a committee function, compared to about 62 percent of respondents in medium and large libraries. The difference among libraries of different sizes is even greater for the "implementing policy" category. Approximately 70 percent of respondents in small libraries mentioned "implementing policy" as a committee role, as compared to 38 percent of those in medium-sized libraries and 54 percent in large libraries.

In an attempt to explain these findings, we analyzed the relationship between committee participation and position level, controlling for library size. If management is overrepresented on committees in the smaller libraries in our sample, it may be that the representation of management, rather than the size of the library, is accounting for the stronger role of committees in smaller libraries. This reasoning was not supported by our analysis. It appears that committees in small academic libraries actually are being used more 
TABLE 5

PERCEPTIONS OF HOW COMMITTEES SHOULD BE USED

\begin{tabular}{lll}
\hline & \multicolumn{2}{c}{ Strongly Agree/Agree } \\
\cline { 2 - 3 } Committee Functions & $N$ & $\%$ \\
\hline The main role of a committee should be to exchange ideas & 19 & 31.1 \\
$\quad$ and information. & 21 & 31.8 \\
A committee should be able to recommend, but never to decide. & 31 & 50.0 \\
Committees should be used to establish library policies. & 34 & 54.0 \\
\hline
\end{tabular}

Percentages are based on the number of valid responses received.

often in significant roles than in medium-sized and larger libraries.

\section{HOW SHOULD COMMITTEES BE USED?}

The previous section describes committee performance in libraries. But we were also interested in respondents' opinions about the roles that they would like to see committees play in their libraries. Respondents' perceptions were measured through the use of a Likert-type scale on the statements in table 5 . Response categories were: Strongly Agree, Agree, Disagree, and Strongly Disagree. The combined responses in the Strongly Agree and Agree categories are shown in table 5 .

An overview of the responses shows that the majority of librarians in our sample are dissatisfied with the use of committees solely for fact-finding and advising. Only about 31 percent of the respondents believe that the main role of a committee should be information exchange. A similar percentage agreed with the statement "A committee should be able to recommend, but never to decide." Our respondents were split on their opinions about giving committees the authority to establish and implement policy. About 50 percent of our respondents would like to see committees establish policy and 54 percent would like committees to have the authority to implement policy.

To better understand these relationships, we looked for variations across organizational and personal variables. We were especially interested in the relationship between library size and respondents' opinions on committee use, since our analysis showed that smaller libraries are using committees for policy related decisions more often than larger libraries. While none of the relationships between library size and the five committee function variables was statistically significant, our analysis shows some interesting trends. Respondents in smaller libraries like the role that committees are assuming in their libraries and would be dissatisfied with the use of committees in less significant ways. Only 12.5 percent of the respondents from small libraries agreed with the statement, "The main role of a committee should be to exchange ideas and information." The positive response rate of these librarians rises at each level of increased authority for committees, with the policyrelated functions showing the highest level of agreement. In fact, nearly 56 percent agree that committees should be used to establish policy and 71 percent believe that committees should have the authority to implement policy.

While respondents from mediumsized and large libraries show dissatisfaction with information-exchanging roles, they are split on their opinions about the use of committees for establishing and implementing policy. While the majority of these respondents seem to want committees to play a more significant role in library management, about half indicate reluctance to give committees the authority for implementing and establishing policy.

\section{PERSONAL BENEFITS OF COMMITTEE SERVICE}

As discussed, the literature is full of information supporting the idea that individuals who participate in decisions 


\section{TABLE 6}

ATTITUDES OF LIBRARIANS TOWARD

PERSONAL BENEFITS OF COMMITTEE SERVICE

\begin{tabular}{llc}
\hline & \multicolumn{2}{c}{ Very/Somewhat Important } \\
\cline { 2 - 3 } Benefits of Committee Work & $N$ & $\%$ \\
\hline Chance to influence library policy and operations. & 63 & 94.0 \\
$\begin{array}{l}\text { Gaining knowledge of operations in other departments } \\
\text { of the library. }\end{array}$ & 63 & 91.3 \\
$\begin{array}{l}\text { Becoming better acquainted with co-workers } \\
\text { Learning about the library's administrative policies and }\end{array}$ & 55 & 82.1 \\
$\quad$ management philosophy. & 52 & 76.5 \\
$\begin{array}{l}\text { Chance to influence hiring decisions. } \\
\text { Chance to learn about new products and resources for }\end{array}$ & 49 & 75.4 \\
$\quad$ libraries. & 47 & 74.6 \\
Gaining recognition for knowledge and abilities & 39 & 60.9 \\
Learning about library operations within my department. & 32 & 51.6 \\
Relief from routine job duties. & 20 & 30.3 \\
\hline
\end{tabular}

Percentages are based on the number of valid responses received.

involving their work are more satisfied than those who lack this input. This has been documented by a number of studies that have correlated dimensions of job satisfaction with levels of employee participation in workplace decision making. ${ }^{16}$ Our interest in this issue is similar in that it centers on looking at the relationship between job satisfaction and employee influence through committee service. But we decided to take a slightly different approach to investigating the issue. An important dimension of job satisfaction is the extent to which individuals believe their personal needs are being met through their work. ${ }^{17}$ We attempted to assess the extent to which committee work contributes to this perception. Our respondents' perceptions were assessed through a series of statements about the personal benefits of committee work. These statements were constructed on the basis of the literature on committee functions. ${ }^{18}$

Our respondents were asked to rank the statements in table 6 as very important, somewhat important, or not important. An additional item, "Serving on committees helps me perform my job better" (table 11) taps global perceptions of the benefits of committee work for library positions. Responses to this item are included in this part of our discussion.
Table 6 shows the distribution of positive responses (very important, somewhat important) for each statement. The most notable trend in the distribution is the large number of items receiving a positive response. While the majority of librarians in the sample do not see committee work as providing relief from routine job duties (about 70 percent) and only about half see committee service as a way to increase their knowledge about library operations within their own departments (nearly 52 percent), most agree that committee work provides opportunities for job enrichment and avenues for influencing library policy. The category "chance to influence library policy and operations" received the highest number of positive responses ( 94 percent), followed by "gaining knowledge of operations in other departments of the library" (91 percent). Respondents also value the social dimension of committee work. Eighty-two percent of the sample rated "becoming better acquainted with co-workers" as either "very important" or "somewhat important." Despite the positive attitude respondents hold toward the personal benefits of committee work, only about 56 percent believe that committee service helps them perform their jobs better. 
TABLE 7

PERSONAL BENEFITS OF COMMITTEE WORK BY LIBRARY ORGANIZATION

\begin{tabular}{lccc}
\hline & \multicolumn{3}{c}{ Library Organization } \\
\cline { 2 - 4 } Benefits of Committee Work & $N$ & Centralized \% & Decentralized \% \\
\hline Becoming better acquainted with coworkers & 20 & 56.3 & 21.6 \\
Very important & 35 & 37.5 & 56.9 \\
Somewhat important & 12 & 6.3 & 21.6 \\
Not important & 67 & & \\
Total N & & & \\
Gain knowledge of other departments & 24 & 56.3 & 28.3 \\
Very important & 39 & 37.5 & 62.3 \\
Somewhat important & 6 & 6.3 & 9.4 \\
Not important & 69 & & \\
Total N & & \\
\hline
\end{tabular}

For becoming better acquainted with coworkers: $x^{2}=7.3771 ; d f=2 ; p=.0099$.

For gaining knowledge of other departments: $x^{2}=4.2366 ; d f=2 ; p=.0733$.

To better understand our respondents' perceptions of the personal benefits of committee service, we analyzed the data by several organizational and personal variables. We originally expected that those in physically decentralized organizations would place a high premium on activity that would enhance their acquaintance with the personnel and operations of the larger organization. Our analysis shows the opposite trend (table 7). The benefits of "becoming better acquainted with coworkers" and "gaining knowledge of operations of other departments in the library" were ranked as "very important" more often in centralized organizations than in decentralized systems. Our findings may be explained by the familiarity with autonomy that has been gained by respondents in decentralized systems, and this may lead to their feeling less of a need for awareness about and influence in the larger organization.

Respondents in small libraries were less concerned with learning about other departments through committee work, probably because those in small institutions already have extensive knowledge about other areas (table 8). Those in large libraries were also somewhat less interested in this aspect of committee work than their colleagues in medium-sized libraries, possibly because, in very large institutions, the expectation to know everyone and everything is less feasible than in smaller organizations. Respondents in large libraries, however, find the opportunity to learn the administration's policies and management philosophy more important than respondents in small and medium-sized libraries do. Respondents in small libraries found influencing library policy and hiring decisions to be significantly more important than did respondents in larger libraries. This finding complements our earlier discussion of the relationship between library size and committee use. Small libraries are much more likely than larger libraries to use committees for establishing and implementing policy and have personnel who believe in a strong role for committees within their libraries.

Line and management-level respondents were twice as likely as those in supervisory positions to report that committee work helps them do their jobs better. Supervisors were, however, very interested in influencing library policy, no doubt because they are often at the front line when it comes to implementing policy (table 9). Managers reported interest in influencing library policy through committee work, while linelevel librarians found learning more 
TABLE 8

PERSONAL BENEFITS OF COMMITTEE WORK BY LIBRARY SIZE

\begin{tabular}{|c|c|c|c|c|}
\hline \multirow[b]{2}{*}{ Benefits of Committee Work } & \multicolumn{4}{|c|}{ Library Size } \\
\hline & $N$ & Small \% & Medium \% & Large $\%$ \\
\hline \multicolumn{5}{|c|}{ Gain knowledge of other departments } \\
\hline Very important & 24 & 11.1 & 52.4 & 32.4 \\
\hline Somewhat important & 37 & 88.9 & 38.1 & 56.8 \\
\hline Not important & 6 & - & 9.5 & 10.8 \\
\hline Total $N$ & 67 & & & \\
\hline \multicolumn{5}{|c|}{ Chance to influence library policy } \\
\hline Very important & 29 & 77.8 & 45.0 & 36.1 \\
\hline Somewhat important & 32 & 22.2 & 45.0 & 58.3 \\
\hline Not important & 4 & - & 10.0 & 5.6 \\
\hline Total $N$ & 65 & & & 698 \\
\hline \multicolumn{5}{|c|}{ Chance to influence hiring decisions } \\
\hline Very important & 21 & 66.7 & 35.0 & 23.5 \\
\hline Somewhat important & 27 & 11.1 & 25.0 & 61.8 \\
\hline Not important & 15 & 22.2 & 40.0 & 14.7 \\
\hline Total $N$ & 63 & & & \\
\hline \multicolumn{5}{|l|}{$\begin{array}{l}\text { Learning about the library's } \\
\text { administrative policies }\end{array}$} \\
\hline Very important & 23 & 22.2 & 28.6 & 41.7 \\
\hline Somewhat important & 28 & 22.2 & 57.1 & 38.9 \\
\hline Not important & 15 & 55.6 & 14.3 & 19.4 \\
\hline Total $N$ & 63 & & & \\
\hline
\end{tabular}

For gaining knowledge of other departments: $x^{2}=7.1946 ; d f=4 ; p=.1259$.

For chance to influence library policy: $x^{2}=5.8703 ; d f=4 ; p=.0688$.

For chance to influence hiring decisions: $x^{2}=3.8326 ; d f=4 ; p=.0078$.

For learning about library's administrative policies: $x^{2}=8.2704 ; d f=4 ; p=.0822$.

about library operations within their own departments to be an important function of committee work.

Respondents without faculty status were more likely than those with faculty status to value committee work as a way to gain recognition for their knowledge and abilities, and provide relief from routine job duties (table 10). For respondents with tenure requirements, it may be that publication activities and participation in professional associations outside the library are substituting or complementing the need for internal recognition in the library through committee service. Committee work may also be viewed by these respondents as an obligation added to publication and professional activities, and additional time away from primary job responsibilities.
Our respondents indicate that they receive a number of benefits from their participation in committee work. As discussed, one of the major principles of the participative style of management is the involvement of a wide cross section of employees in significant decision making. That the majority of librarians in our sample ( 94 percent) rated the statement "chance to influence library policy and operations" as important to them suggests that our respondents see committees as an avenue for influencing the management of library operations. This perception did not vary significantly by position rank, position, or service area. Librarians of all position levels and service areas value this function of committee work. Another interesting trend is the importance of committee service as 
TABLE 9

PERSONAL BENEFITS OF COMMITTEE WORK BY CURRENT POSITION

\section{Current Position}

\begin{tabular}{lrrrr}
\cline { 2 - 5 } Benefits of Committee Work & $N$ & Line-level \% & Supervisor \% & Management \% \\
\hline Chance to influence library policy & & & & \\
$\quad$ Very important & 30 & 20.0 & 40.0 & 54.1 \\
$\begin{array}{l}\text { Somewhat important } \\
\text { Not important }\end{array}$ & 33 & 60.0 & 60.0 & 40.5 \\
$\begin{array}{l}\text { Total N } \\
\text { Learning about library operations } \\
\text { within the department }\end{array}$ & 4 & 20.0 & - & 5.4 \\
$\quad \begin{array}{l}\text { Very important } \\
\text { Somewhat important }\end{array}$ & 67 & & & \\
Not important & 12 & 12.5 & 30.0 & 14.7 \\
Total N & 20 & 87.5 & 20.0 & 26.5 \\
\hline
\end{tabular}

For chance to influence library policy: $x^{2}=7.9686 ; d f=4 ; p=.0927$

For learning about library operations within the department: $x \underline{2}=15.2447 ; d f=4 ; p=.0042$.

TABLE 10

PERSONAL BENEFITS OF COMMITTEE WORK BY FACULTY STATUS

\begin{tabular}{lccc}
\hline Benefits of Committe Work & $N$ & $\begin{array}{c}\text { Without Faculty } \\
\text { Status \% }\end{array}$ & Faculty Status \% \\
\hline Gain recognition for knowledge and abilities & & & \\
$\quad$ Very important & 15 & 40.9 & 14.3 \\
Somewhat important & 24 & 36.4 & 38.1 \\
Not important & 25 & 22.7 & 47.6 \\
Total N & 64 & & \\
Provide relief from routine job duties & & & \\
Very important & 5 & 8.7 & 7.0 \\
Somewhat important & 15 & 39.1 & 79.1 \\
Not important & 46 & 52.2 & \\
Total N & 66 & & \\
\hline
\end{tabular}

For gaining recognition: $x^{2}=6.6678 ; d f=2 ; p=.0552$.

For providing relief from routine job duties: $x^{2}=5.7930 ; d f=2 ; p=.0552$.

an avenue for learning. The type of learning provided by committee work varies in importance by category of library and the dimensions of our respondents' positions. Yet almost all of the librarians in our sample indicated that their committee work provides an important opportunity for broadening their knowledge of internal and/or external library operations.

\section{BENEFITS TO THE ORGANIZATION}

Participative practices will remain viable only as long as they are viewed as beneficial to organizational performance and job satisfaction by a wide cross section of employees. As identified by Seashore, "commonly accepted features" of participative organizations include:

- A high level of communication among employees of all ranks

- The ability for employees of all ranks to influence the goals of the organization

- A high level of interaction among employees

- A high level of mutual confidence and trust among employees. ${ }^{19}$ 
TABLE 11

ATTITUDES OF LIBRARIANS TOWARD COMMITTEE FUNCTIONS

\begin{tabular}{|c|c|c|c|}
\hline \multirow[b]{2}{*}{$+1-$} & \multirow[b]{2}{*}{ Committee Function } & \multicolumn{2}{|c|}{ Strongly Agree/Agree } \\
\hline & & $N$ & $\%$ \\
\hline$(+)$ & Committees promote creativity through the exchange of ideas. & 59 & 89.4 \\
\hline$(+)$ & Committees promote coordination among departments. & 59 & 86.8 \\
\hline$(-)$ & $\begin{array}{l}\text { Most decisions reached by committees are compromises rather } \\
\text { than best decisions. }\end{array}$ & 30 & 45.5 \\
\hline$(+)$ & Committees promote communication between departments. & 62 & 91.2 \\
\hline$(-)$ & Committees breed conformity and stifle creativity. & 15 & 24.2 \\
\hline$(+)$ & $\begin{array}{l}\text { Most professionals in my library have an equal chance of } \\
\text { serving on committees. }\end{array}$ & 40 & 58.0 \\
\hline$(+)$ & Committees help libraries function efficiently. & 42 & 68.9 \\
\hline$(+)$ & Serving on committees helps me perform my job better. & 34 & 55.7 \\
\hline$(+)$ & $\begin{array}{l}\text { Committees promote communication between employees of } \\
\text { different ranks. }\end{array}$ & 49 & 73.1 \\
\hline$(-)$ & $\begin{array}{l}\text { Committee work often requires knowledge and experience } \\
\text { outside my expertise. }\end{array}$ & 25 & 37.3 \\
\hline$(-)$ & $\begin{array}{l}\text { I often feel uncomfortable contributing my ideas in committee } \\
\text { meetings. }\end{array}$ & 12 & 17.9 \\
\hline$(-)$ & While they may be useful, committees waste too much time. & 33 & 50.8 \\
\hline$(-)$ & $\begin{array}{l}\text { The main role of a committee should be to exchange ideas and } \\
\text { information. }\end{array}$ & 19 & 31.1 \\
\hline$(-)$ & A committee should be able to recommend, but never to decide. & 21 & 31.8 \\
\hline$(+)$ & Committees should be used to establish library policies. & 31 & 50.0 \\
\hline$(+)$ & Committees should be used to implement library policies. & 34 & 54.0 \\
\hline$(-)$ & I dislike being held responsible for committee decisions. & 18 & 31.6 \\
\hline$(-)$ & $\begin{array}{l}\text { I resent the time that committee work takes from my primary } \\
\text { duties. }\end{array}$ & 26 & 42.6 \\
\hline$(-)$ & $\begin{array}{l}\text { Management is over-represented on the committees in my } \\
\text { library. }\end{array}$ & 18 & 27.7 \\
\hline$(+)$ & The committee is the best way to assure informed decisions. & 34 & 61.8 \\
\hline
\end{tabular}

Percentages are based on the number of valid responses received.

In our survey, we attempted to assess the contribution of committee work to these features. We also reasoned that to be considered a viable component of participative practices, employees must have confidence in the ability of committees to have a significant impact on their organization. Measures of this impact have been incorporated into this section of the analysis. Our respondents' perceptions of the influence of committee work in their libraries were measured through a twenty-item Likert-type scale (table 11). The scale is composed of an equal number of positive and negative items. ${ }^{20}$ Respondents were asked to indi- cate their level of agreement with each scale item, using the following categories: strongly agree, agree, disagree, strongly disagree. Table 11 shows the percentage of combined responses in the "strongly agree" and "agree" categories. The direction of the statement (positive, negative) is indicated at the beginning of each scale item.

As discussed, interaction and communication are viewed as important features of participative organizations. The literature on organizations emphasizes the importance of the committee as a mechanism for coordinating the diverse activities performed by individuals and 
separate administrative units within organizations. ${ }^{21}$ The importance of this role for committees in academic libraries is supported by our analysis. Over 90 percent of the respondents agreed with the statement, "Committees promote communication between departments." Other statements receiving a high, positive response rate are "Committees promote creativity through the exchange of ideas" ( 89 percent) and "Committees promote coordination among departments" (nearly 87 percent). Our respondents were somewhat less likely to view committee service as a way to promote communication between employees of different ranks (73 percent). Although these positive aspects of committees were recognized, a number of our respondents expressed a lack of confidence in the ability of committees to contribute to the overall efficiency of their libraries. Only about two-thirds (almost 69 percent) of the librarians responded positively to "Committees help libraries function efficiently."

An overview of our results also shows a lack of confidence in the decision-making ability of committees. Close to half (45.5 percent) of our sample agreed with the statement, "Most decisions reached by committees are compromises rather than best decisions" and about onefourth ( 24 percent) of our respondents believe that committees breed conformity and stifle creativity. About one-third (almost 32 percent) of the librarians in our sample report that they dislike being held responsible for committee decisions. When asked to provide an overall assessment of the ability of committees to provide organizations with sound decisions, slightly under two-thirds (nearly 62 percent) of the sample responded positively to the statement, "The committee is the best way to assure informed decisions."

As discussed, the amount of time consumed by committee meetings and related work is often cited as one of the more negative aspects of committee service. Our analysis indicates that a significant number of our respondents would agree with this complaint. Slightly over half (about 51 percent) of our respondents agreed with the statement, "While they may be useful, committees waste too much time," and about 43 percent indicated that they resent the time committee work takes from primary job duties. The only significant relationship between library size and any of the scale items was obtained for the global measure of the committee's contribution to the effectiveness of the library. All of the librarians in the "small" library category agree that committees "help libraries function efficiently"; only about 64 percent of those in medium and large libraries agree with this statement. This finding may be explained by the different roles that committees play in libraries of various sizes. As discussed, establishing and implementing policy seems to be a fairly routine function of committees in small libraries. This function is much less likely to be assumed by committees in larger libraries. Serving on committees that have a significant impact on the organization seems to be reflected in the perception that libraries are functioning effectively because of committee input.

\section{FAVORABILITY INDEX}

Summing across the scale items in table 11 and dividing by the number of valid responses for each individual in our sample provides us with an index of favorable/unfavorable attitudes toward committees. By this method, it is possible for respondents to have scale values ranging between 1 and 4 . An index value of 1 would indicate that respondents expressed an unfavorable attitude toward all scale items in table 11, while an index value of 4 would result from unanimously favorable responses to all scale items. The index values of our respondents ranged from a low of 1.89 to a high of 3.84 , with an average score of 2.759 .

The higher the position rank of our respondents, the more likely they were to express a favorable attitude toward committees (table 12). Only about 20 percent of all line-level employees had highly positive index scores, as compared to 45.5 percent of supervisors, and 62.5 percent of managers. This finding 
TABLE 12

FAVORABILITY TOWARD COMMITTEES BY CURRENT POSITION

\begin{tabular}{lcccc}
\hline & \multicolumn{4}{c}{ Current Position } \\
\cline { 2 - 5 } Favorability Index & $N$ & Line-level \% & Supervisory \% & Management \% \\
\hline Low & 35 & 80.0 & 54.5 & 37.5 \\
High & 35 & 20.0 & 45.5 & 62.5 \\
Total $N$ & 70 & & & \\
\hline
\end{tabular}

$x^{2}=5.4818 ; d f=3 ; p=.0287$.

TABLE 13

FAVORABILITY TOWARD COMMITTEES BY LIBRARY SIZE

\begin{tabular}{lcccc}
\hline & \multicolumn{4}{c}{ Library Size } \\
\cline { 2 - 5 } Favorability Index & $N$ & Small \% & Medium \% & Large \% \\
\hline Low & 35 & 30.0 & 40.9 & 62.2 \\
High & 35 & 70.0 & 59.1 & 37.8 \\
Total $N$ & 70 & & & \\
\hline
\end{tabular}

$x^{2}=4.5029 ; d f=2 ; p=.03716$

TABLE 14

FAVORABILITY TOWARD COMMITTEES BY HOW OFTEN COMMITTEE RECOMMENDATIONS ARE IMPLEMENTED

\begin{tabular}{lcccc}
\hline & \multicolumn{4}{c}{ "How often are committee recommendations implemented?" } \\
\cline { 2 - 5 } Favorability Index & $N$ & Rarely \% & Sometimes \% & Often \% \\
\hline Low & 33 & 66.7 & 56.8 & 34.8 \\
High & 33 & 33.3 & 43.2 & 65.2 \\
Total $N$ & 66 & & & \\
\hline
\end{tabular}

$\mathrm{x} 2=3.472 ; \mathrm{df}=2 ; \mathrm{p}=.0715$.

did not support our expectations. Since committees are supposed to provide opportunities for rank-and-file employees to have a voice in their organization, we expected line-level employees to express a much more positive attitude toward committee work than other employees. It may be that managers tend to focus on the use of committee work, while the perspective of line-level people is on process, and that these different views are contributing to the direction of this relationship. Perhaps line-level personnel have a more limited view than supervisors and managers of the benefits of committee work to the larger organization, and are more likely to focus on the time commitment and other disadvantages of the actual dynamics of committee work.

Those in large and medium-sized libraries express a less favorable attitude toward committees than those in small libraries (table 13). Small libraries are much more likely than larger libraries to use committees for policy-related tasks, and having this input seems to lead to a more positive attitude toward committee service.

Respondents who report that committee recommendations are often implemented in their libraries are much more positive about committee work than those who report that recommendations are rarely or sometimes implemented (table 14). Again, this supports the idea that librarians who see that their committee service has a significant impact on their organization will be positive about this aspect of their work.

\section{CONCLUSIONS}

One of the major features that distinguishes participative organizations from others is the provision of opportunities for communication, interaction, and influence across functional and status lines. This study shows that committees 
in academic libraries are providing this opportunity through involving librarians from a variety of ranks and service areas in the decision-making processes of their libraries. These committees are providing opportunities for a wide cross section of librarians to communicate and learn about the jobs of others in their libraries, and administrative policies and procedures. While the communication and learning functions of committees are important, the basic tenet of participative management is to provide rank-andfile employees with the authority to shape the goals and structure of their host organization, and our study indicates that some libraries are using committees in this role to a greater extent than others. Some libraries are using committees primarily for fact-finding and information-gathering, while reserving the authority for policy decisions for administrative personnel.
Our study shows that the larger the library, the more likely it is that committees will be used solely for these functions. Librarians who serve on factfinding and information gathering committees tend to have a less positive attitude than others about their committee service. While they express dissatisfaction with the limited impact of committees, they are cautious about the use of committees in more significant roles. This caution is not a managementdominated attitude, but is expressed across all position ranks. Our study shows that the majority of committee work carrying policy implications is conducted in smaller libraries, although this function is found in libraries of all sizes. Librarians who serve on committees with the authority to establish and implement policy believe in this role for committees, and are positive about the ability of committees to benefit the organization.

\section{REFERENCES AND NOTES}

1. Louis Kaplan, "On the Road to Participative Management: The American Academic Library," Libri 38 (1988): 315-20.

2. Ibid., 317.

3. Hano Johannsen and G. Terry Page, International Dictionary of Management, 4th ed. (London: Kogan Page, 1990), 218.

4. Maurice P. Marchant, "Participative Management as Related to Personnel Development," Library Trends (July 1971): 48-59.

5. Allen B. Veaner, "Administrative Theories, Business Paradigms and Work in the Academic Library," Advances in Library Administration and Organization 9 (1991): 1-26.

6. Marchant, "Participative Management as Related to Personnel Development," 49.

7. Kaplan, "On the Road to Participative Management," 320.

8. Richard Eggleton, "Academic Libraries, Participative Management, and Risky Shift," Journal of Academic Librarianship: 271-73.

9. Ibid., 272.

10. Stanley E. Seashore, "Main Themes from 'Staff Participation in Management'," Minutes of the Meeting of the Association of Research Libraries (Chicago: ARL, Jan. 17-18, 1970), 38-39.

11. The random sample of 125 academic librarians was drawn from the $1993 / 94$ ALA Handbook of Organization and Membership Directory (Chicago: ALA). Three of the potential respondents were dropped from the sample because of insufficient location information.

12. All analyses were done using SPSSX. Nominal and ordinal data were analyzed using chi-square tests. Some interval level data were collapsed into logical categories and analyzed through chi-square tests. All reported $p^{\prime}$ s for chi-square reflect Yates' correction.

13. Rollie Tillman Jr., "Committees on Trial," Harvard Business Review 38 (May/June 1960): 6-12, 162-68, 197-74.

14. Developed on the basis of categories in ARL SPEC kits.

15. Maurice P. Marchant, Participative Management in Libraries (Westport, Conn.: Greenwood), 1.

16. Summaries of a number of these studies are found in: Fred M. Peterson, "The Use of Committees in the Governance, Management, and Operations of Three Major University Libraries" (Ph.D. diss. Indiana University, 1977), See also: Bonnie Horenstein, "Job Satisfac- 
tion of Academic Librarians: An Examination of the Relationships between Satisfaction, Faculty Status, and Participation," College \& Research Libraries 54 (May 1993): 255-69.

17. T. E. Anastasi, "Management Committees: Why, How and Who?" Advanced Management Journal 29 (July 1964): 67-71.

18. Based on a summary of committee functions in Peterson, "The Use of Committees," 20-35.

19. Seashore, "Main Themes from 'Staff Participation in Management'," 38-39.

20. Many of the scale items were derived from research reported in Peterson, "The Use of Committees," 375-93; and Rollie Tillman Jr., "Committees on Trial," 6-12. Other items were developed specifically for this study.

21. Peterson, "The Use of Committees," 21-25.

\section{INDEX TO ADVERTISERS COLLEGE \& RESEARCH LIBRARIES}

ACRL

ALA

Biosis

Blackwell

Walter deGruyter

Greenwood

Library Technologies

Pais

Readmore

Todd
477, 498, 509

470,528

cover 2

cover 3

474

469

478

527

510

cover 4 


\title{
58,000 AMERICANS DIED THERE.
}

\author{
365,OOO WERE WOUNDED.
}

OVER 2,000 ARE STILL MISSING.

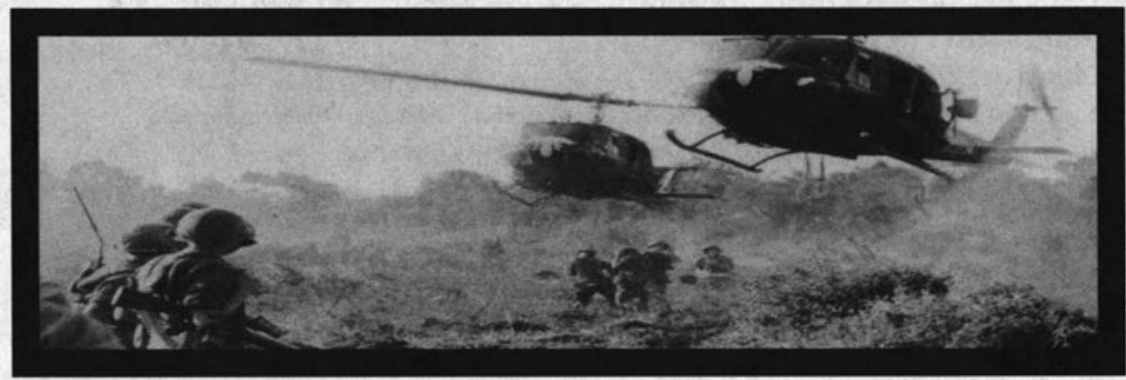

\section{HOW RISKY AN INVESTMENT IS VIETNAM TODAY?}

A generation ago, Americans risked their lives in Vietnam. Today, they're risking investments. With the trade embargo lifted, Americans have swapped fatigues for pinstriped suits.

U.S.-Vietnam trade is just one of the important public and social policy issues you can explore through PAIS International. PAIS gives you instant access to an index of some 400,000 hard-to-find articles, books, government

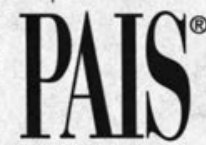

documents, statistical directories and more. It references literature published around the globe. And now it's even available on leased tape.

So before you risk time and money, turn to the definitive source. PAIS.

\section{NO ONE LOOKS AT THE WORLD LIKE PAIS}

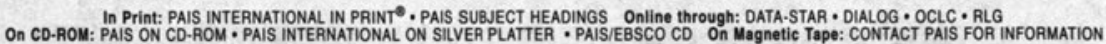



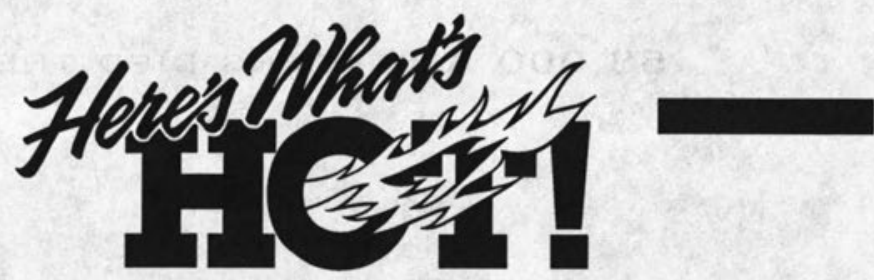

The Whole Library Handbook II

George Eberhart

The sequel for which everyone has been waiting. Not just a second edition but a whole new book. Packed with facts and figures, handy advice and guidelines, library lore and wit and the essentials of librarianship, the handbook includes a great deal of information on technology, including the Internet. More than 75 percent new and updated materials. Perfect for librarians, library students, support personnel, friends, and trustees.

\$30.00pbk. - approx. 500p. • 1995 - ALA Order Code 0646-X-0011

New! Management ...

Outsourcing Cataloging, Authority Work, and Physical Processing: A Checklist of Considerations Commercial Technical Services Commitee, ALCTS

Marie Kascus and Down Hale, editors

S12.00pbk. - opprox. 40p. - 1995

ALA Order Code 3449-5-0011

The Information Superhighway....

The Internet Troubleshooter: Help for the Logged-On and Lost Nancy Regina John and Edward J. Valouskas

\$20.00spiral-bound $\bullet 145 \mathrm{p}$. 1994

ALA Order Code 0633-8-0011

After the Electronic Revolution, Will You Be the First to Go?

Arnold Hirshon, editor

S18.00pbk. - 62p. - 1993

ALA Order Code 7650-6-0011

Preservation...

A Core Collection in Preservation, Revised Edition Lisa L. Fox

Don Thompson and Joan ten Hoor, compilers

\$5.00pbk. - 43p. - 1993

ALA Order Code 7633-6-0011
Cafaloging...

Guidelines for Bibliographic Description of Interactive Multimedia

AlCTS Interoctive Multimedia Guidelines

Review Task Force

Laurel Jizba, editor

S12.00pbk. - 43p. 1994

ALA Order Code 3445-5-0011

Subject Analysis...

Headings for Tomorrow: Public Access Display of Subject Headings ALCSS Subject Anolysis Committee

Martha M. Yee, editor

S18.00bpk. - 51p. - 1992

ALA Order Code 3415-5-0011

To Order-Call 800-545-2433 and press 7

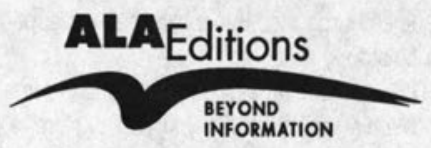

Americon Library Association Book Order Fulfillment 155 N. Wacker Chicogo, II 60606 